Article

\title{
Biocontrol Potential of Some Entomopathogenic Fungal Strains Against Bean Aphid Megoura japonica (Matsumura)
}

\author{
Duy Nam Trinh ${ }^{1,2, *}$, Thi Kim Lien $\mathrm{Ha}^{2}$ and Dewen Qiu ${ }^{1, *}$ \\ 1 State Key Laboratory of Plant Diseases and Insect Pests, Institute of Plant Protection, Chinese Academy of \\ Agricultural Sciences, Beijing 100193, China \\ 2 Plant Protection Research Institute, Hanoi, Vietnam; kimlientta@gmail.com \\ * Correspondence: trinhduynam09@yahoo.com.vn (D.N.T.); qiudewen@caas.cn (D.Q.); \\ Tel.: +86-10-8210-5929 (D.Q.)
}

Received: 4 February 2020; Accepted: 31 March 2020; Published: 4 April 2020

\begin{abstract}
This research reported the in vitro pathogenicity of Verticillium lecanii strains, L2 and L5, and Beauveria bassiana strains, B76 and B252, against Megoura japonica using leaf-dip method. The virulence potential of these four entomopathogenic fungal strains of $V$. lecanii and of $B$. bassiana were compared between fungi conidia (concentrations $1 \times 10^{6}, 1 \times 10^{7}$, and $1 \times 10^{8}$ conidia $\mathrm{mL}^{-1}$ ) and culture filtrate. Moreover, binary combination of four different fungal strains (L2 + B76, B76 + L5, $\mathrm{L} 2+\mathrm{B} 252$, and $\mathrm{L} 2+\mathrm{B} 76+\mathrm{B} 252+\mathrm{L} 5)$ were evaluated against $M$. japonica under control condition. Aphid mortality was recorded after two, four, six, and eight days of post-treatment. In the conidial concentration bioassay, strain B76 showed maximal mortality (85.3\%) against bean aphid, and strain L5 showed the lowest effect $(60.0 \%)$ at the highest concentration $\left(1 \times 10^{8}\right.$ conidia $\left.\mathrm{mL}^{-1}\right)$ at eight days post-treatment. Whereas, binary combinations of B76 and L2 strains showed the highest effect against M. japonica $(90.5 \%)$ than other combinations. Moreover, in comparison with the effect of filtrate and conidia bioassay, $91.4 \%$ and $84.1 \%$ were achieved in strain B76, and the lowest effect $(63.8 \%$ and $55.1 \%$ ) was recorded in strain L5.
\end{abstract}

Keywords: Verticillium lecanii; Beauveria bassiana; Megoura japonica; binary combination; filtrates; conidial

\section{Introduction}

The bean aphid Megoura japonica (Matsumura) is one of the most dangerous agricultural insect pests on legume plants, such as common bean, soybean, and mung bean [1]. Bean aphid is distributed widely all over the world [2]. They suck cell sap from plants and also transmit various viruses in different crops [3]. The management of M. japonica is through synthetic pesticides. However, the unselective application of pesticides has resulted in many visible problems, such as resistance to pesticides, killing natural enemies, environmental pollution, and human health issues [4]. To overcome problems related to widespread use of chemical pesticides, alternative methods such as biocontrol substances have extensively been researched in the world. Many microbial insecticides based on pathogenic organisms, such as virus, bacteria, fungus, and nematode, have played a significant role in the field of crop protection and are being used to control an extensive range of insects [5-9].

Entomopathogenic fungal strains, including Verticillium lecanii, Beauveria bassiana, Isaria fumosorosea, and Metarhizium anisopliae, were used as the specific biological pesticides, which are environmentally friendly and can be used against many sucking insect pests [5,10-12]. Spores germinated after attaching to the epidermis of the host insects, and the hyphae penetrate the body of the insects, which causes the death of the host within a few days $[13,14]$. In addition, these entomopathogenic fungi have no or 
little harmfulness on mammals. Their residuals are target specific and less vulnerable to resistance evolution $[15,16]$. These virulent fungi were focused on by researchers in the past decades for their potential as biological control agents around the world, and these could exist at the epizootic or enzootic levels in their host population.

$V$. lecanii and B. bassiana are among the most well researched virulent entomopathogenic fungi belonging to order of Hypocreals. They have a wide range of insect pest colonization $[17,18]$. These two kinds of fungal strains are easily collected from the phylloplane of vegetation, as well as from infected insects and soil $[19,20]$. As a bio-insecticide, $V$. lecanii has been used to control black bean aphid Aphis fabae (Hemiptera: Aphididae) under control conditions [21]. The entomopathogenic fungi have been developed as one of the major new bioactive agents for plant pathogen and insect pest control [22-24]. Fungal conidia are produced asexually and become the basis of infection in insect pests of crops. Infection through conidia starts when they are attached to the host cuticle, then germinate following the activation of the enzymatic reaction and invaded the body of the insects by germ tube, appressoria, and penetration pegs [25]. Refined culture filtrates of entomopathogenic fungi, V. lecanii and B. bassiana, decreased the reproductive rate of aphids $[26,27]$ and prevented feeding of the larva of Spodoptera littoralis and Bemisia tabaci $[28,29]$. Increased fungus concentration decreased the number of adult parasitoids and also negatively affected its developmental stages [30]. Filtrate culture contains many enzymes like chitinases, lipases, and protease, and these enzymes help in the infection process by degrading the cuticle of insects. The concentration of an enzyme can be enhanced by the use of different additives in the culture media, like colloidal chitin [27].

This paper focused on the evaluation of the efficacy of our collected fungal strains (V. lecanii and B. bassiana) with different application materials (conidia, filtrate) on bean aphids. Furthermore, we also aimed to determine the combined effect of different entomopathogenic fungal strains against bean aphids. This result could be helpful for establishing an effective integrated pest management method which could reduce bean aphid population below economic thresholds, while minimizing the use of synthetic chemical pesticides.

\section{Results}

\subsection{Inhibition Effect of Different Concentrations of the Fungal Spore on Bean Aphid}

The conidial bioassay results showed the significant effect of the different fungal trains $(p<$ 0.01; Table 1). Moreover, the factorial analysis of variance revealed a significant effect of different concentrations $(\mathrm{F}=296.72, p<0.01)$, different time intervals $(\mathrm{F}=* * * * * *, p<0.01)$, and their interaction $(p<0.01$, Table 1). All strains of B. bassiana and V. lecanii caused significant bean aphid mortality at all different concentrations. The maximum effect of the fungal strain $(85.3 \%)$ was collected on the eighth day after treatment with the concentration of $1 \times 10^{8}$ conidia $\mathrm{mL}^{-1}$ from strain B76, whereas the minimum effect $(71.4 \%)$ was collected at the lowest concentration of B76 (i.e., $1 \times 10^{6}$ conidia $\mathrm{mL}^{-1}$, Figure 1). The virulence from fungal strain B252 against $M$. japonica showed a similar tendency to the condition of strain B76. The highest mean effect $(66.0 \%)$ of strain B252 was collected with a concentration of $1 \times 10^{8}$ conidia $\mathrm{mL}^{-1}$ at $8 \mathrm{dpi}$. The minimum mean effect of strain B252 (49.9\%) was collected at the lowest concentration $\left(1 \times 10^{6}\right.$ conidia $\left.\mathrm{mL}^{-1}\right)$. Similarly, the effect of $V$. lecanii strains, L2 and L5, on M. japonica presented that corrected mortality of bean aphid improved with the exposure time and concentration of fungal strains (Figure 1). 
Table 1. Analysis of variance (ANOVA) for the mortality of $M$. japonica by three different concentrations from four entomopathogenic fungi strains at different times against bean aphids.

\begin{tabular}{cccccc}
\hline Source of Variation & DF & Sums of Squares & Mean Squares & F Ratio & Prob \\
\hline Treatment & 4 & $39,204.6$ & 9801.15 & $* * * * * *$ & 0.000 \\
Concentration & 2 & 3151.77 & 1575.88 & 296.72 & 0.000 \\
Time & 3 & $57,007.1$ & 19002.4 & $* * * * * *$ & 0.000 \\
Treatment $\times$ Concentration & 8 & 849.592 & 106.199 & 20.00 & 0.000 \\
Treatment $\times$ Time & 12 & $12,258.7$ & 1021.56 & 192.34 & 0.000 \\
Concentration $\times$ Time & 6 & 625.468 & 104.245 & 19.63 & 0.000 \\
Treatment $\times$ Concentration $\times$ Time & 24 & 454.597 & 18.9415 & 3.57 & 0.000 \\
RESIDUAL & 120 & 637.332 & 5.31110 & & \\
Total & 179 & $114,189$. & 637.928 & & \\
CV $\%$ & 7.0 & & & & \\
\hline
\end{tabular}

CV\%: Coefficient of variation.

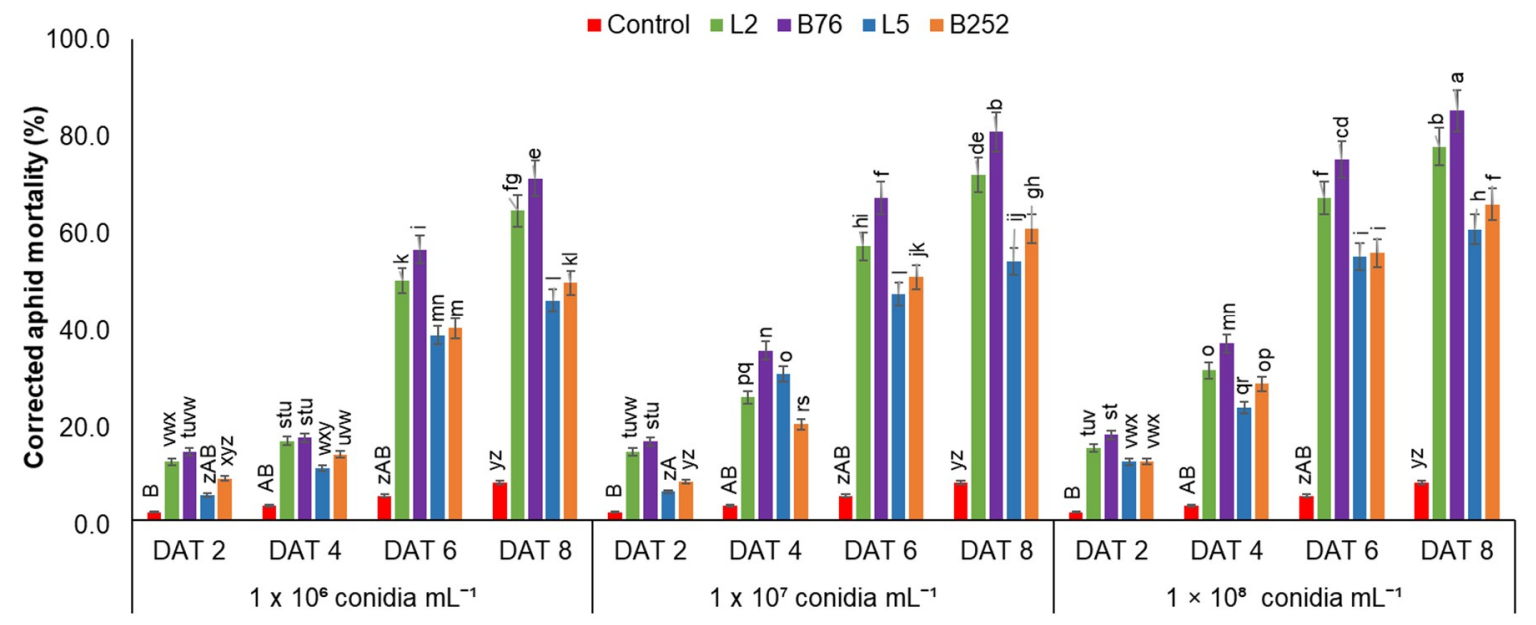

Figure 1. The mortality of Megoura japonica by different concentrations of Verticillium lecanii (L2 and L5) and Beauveria bassiana (B76 and B252) spores at different time intervals. Columns show the mortality of aphids with different fungal strains \pm SE $(n=50)$. The different letters express significant differences between different treatments (three-way factorial analysis of variance (ANOVA); least significant difference (LSD) test at $\alpha=0.05)$. DAT: Days after treatment.

\subsection{Fungal Strain Combinations Against Bean Aphid}

In the combination bioassays test, the results showed a high significant effect of all treatments $(\mathrm{F}=$ 618.56; $p<0.01)$, the different time intervals $(\mathrm{F}=775.30, p<0.01)$, and the interaction between different times and different treatments on fungal strains $(\mathrm{F}=40.60, p<0.01$, Table 2). The highest inhibition effect of the fungal strain $(90.5 \%)$ was observed for L2 + B76, while the effect of the combination of B76 + L5 was $81.1 \%$. Binary combination of L2 + B252 caused $71.6 \%$ corrected bean aphid mortality (Figure 2). Nevertheless, for the combination of four different fungal strains (L2 + L5 + B76 + B252), the bean aphid mortality rate was recorded as $69.4 \%$. This phenomenon was most probably due to the reduced number of spores of the high virulence strain (B76 and L2) in the combination (B76 + $\mathrm{L} 2+\mathrm{B} 252+\mathrm{L} 4)$. So, its effect was reduced to be significantly lower against $M$. japonica than other combinations (Figure 2). 
Table 2. Analysis of variance (ANOVA) for the mortality of M. japonica by the binary combinations from four fungal strains of $V$. lecanii and B. bassiana at different time intervals.

\begin{tabular}{cccccc}
\hline Source of Variation & DF & Sums of Squares & Mean Squares & F Ratio & Prob \\
\hline Treatment & 4 & $20,964.9$ & 5241.22 & 618.56 & 0.000 \\
Time & 3 & $19,708.0$ & 6569.34 & 775.30 & 0.000 \\
Treatment $\times$ Time & 12 & 4127.90 & 343.992 & 40.60 & 0.000 \\
RESIDUAL & 40 & 338.932 & 8.47329 & & \\
Total & 59 & $45,139.7$ & 765.080 & & \\
CV $\%$ & 7.2 & & & &
\end{tabular}

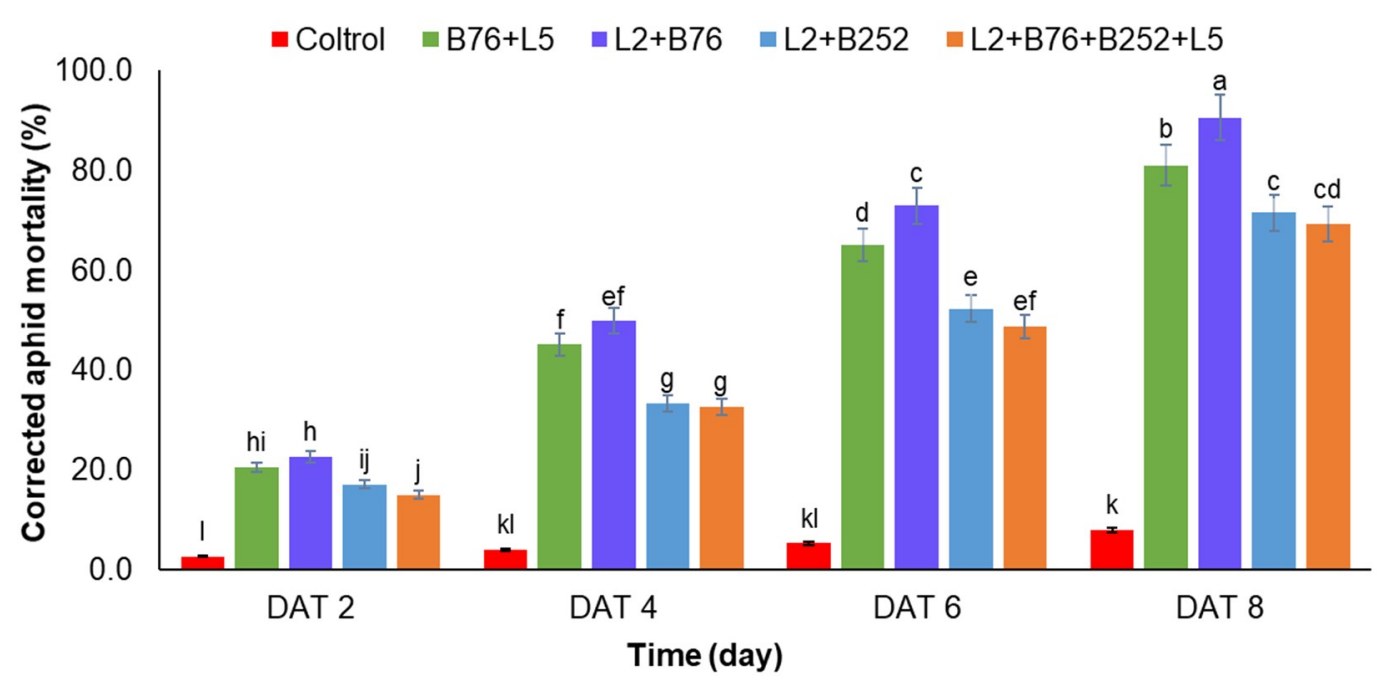

Figure 2. The mortality of Megoura japonica by the binary combinations from strains of Verticillium lecanii and Beauveria bassiana (L2 + B76, B76 + L5, L2 + B252, L2 + B76 + B252 + L5, and control) recorded at different time intervals. Columns show the bean aphid mortality with different fungal strains $\pm \mathrm{SE}$ $(n=50)$. The different letters express the significant difference between different treatments (two-way factorial analysis of variance (ANOVA); least significant difference (LSD) test at $\alpha=0.05)$. DAT: Days after treatment.

\subsection{Comparison of the Mortality of Bean Aphid by Fungi Filtrate and Conidia}

The filtrate bioassay results revealed that the overall mean effect of different fungi filtrate against bean aphid was higher in comparison to their conidial treatments. Statistical processing results showed that there was a significant effect of fungal conidia and filtrates on corrected bean aphid mortality $(\mathrm{F}=$ $117.71, p<0.01$, Table 3). The highest effect of the filtrate solution was strain B76, with $91 \%$ recorded on the eighth day of treatment, while the effect of strain B76 conidia was recorded as $84 \%$ on the eighth day of treatment $(p<0.01)$. Other fungal strains had similar results. However, the lowest effect of filtrates and conidia was in fungal strain L5, recorded as $63.8 \%$ and $55.1 \%$, respectively (Figure 3).

Table 3. Analysis of variance (ANOVA) for the comparison of the mortality of $M$. japonica by filtrate and the conidia from different fungal strains (V. lecanii and B. bassiana).

\begin{tabular}{cccccc}
\hline Source of Variation & DF & Sums of Squares & Mean Squares & F Ratio & Prob \\
\hline Treatment & 8 & $15,365.3$ & 1920.66 & 117.71 & 0.000 \\
RESIDUAL & 18 & 293.692 & 16.3162 & & \\
Total & 26 & $15,659.0$ & 602.268 & & \\
CV\% & 6.0 & & & & \\
\hline
\end{tabular}




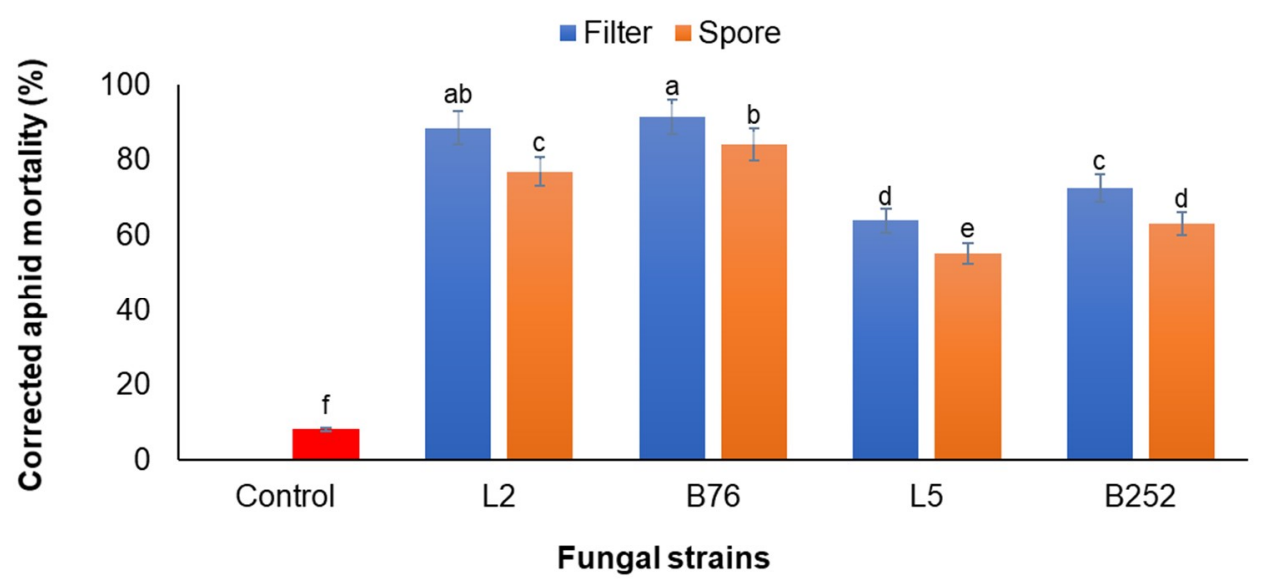

Figure 3. Comparison of the mortality of $M$. japonica by filtrate and the conidia from different fungal strains (V. lecanii and B. bassiana). Columns show the mortality of aphids by different fungal strains $\pm \mathrm{SE}$ $(n=50)$. The different letters express the significant difference between different treatments (one-way factorial analysis of variance (ANOVA); least significant difference (LSD) test at $\alpha=0.05$ ).

\section{Discussion}

Developing biological control methods, based on entomopathogenic fungi with resistance to pathogens and insect pests, is one of the core areas of current biological control research. Many virulent fungal strains were found to be effective against different insect pests [31,32]. This study determined the effect of different entomopathogenic fungi against bean aphid. The results of this study presented that four strains, V. lecanii (L2 and L5) and B. bassiana (B76 and B252), could be effective biocontrol agents against bean aphids. This study result is also similar to previous research showing the effect of different strains of $V$. lecanii and B. bassiana against aphids [26,33].

In all experiments, the effect of fungal strains appeared to be dose and time-dependent and increased by increasing time after application and the conidia concentrations of fungus, [34] which was also demonstrated in our conidial treatment study. They use different concentrations of the entomopathogenic fungus, B. bassiana, against Metopeurum fuscoviride and A. fabae, and reported that the highest concentration $\left(1 \times 10^{8}\right.$ spores $\left.\mathrm{mL}^{-1}\right)$ exhibited the highest mortality percent on seventh day post-treatment. It was also demonstrated that the mortality of aphids increased with time and conidial concentration exposure [35,36]. Similarly, it was described that the mortality percentage was affected by the concentration of conidia, temperature, and exposure time [37]. The mortality percentage was directly proportional to the concentration of conidia using different concentrations of B. bassiana $\left(1 \times 10^{6}, 1 \times 10^{7}\right.$ and $1 \times 10^{8}$ conidia $\left.\mathrm{mL}^{-1}\right)$ Rhopalosiphum padi, Schizaphis graminum, Lipaphis erysimi, and Brevicoryne brassicae. All concentrations were effective for the control of aphids, but the highest concentration $\left(1 \times 10^{8}\right.$ conidia $\left.\mathrm{mL}^{-1}\right)$ caused the highest percentage mortality [38]. The research was conducted for the determination of the virulence of $V$. lecanii and its result showed that concentration of $1 \times 10^{8}$ conidia $\mathrm{mL}^{-1}$ had the best effect, with an $86 \%$ mortality rate of nymphal observed after five days of application [39]. It was also reported that at concentrations of $10^{7}$ and $10^{8}$ conidia $\mathrm{mL}^{-1}$ of $V$. lecanii, the maximum mortality rate of $M$. persicae was recorded as $100 \%$ after 12 days of application [40]. Similarly, the effect of B. bassiana on M. persicae was also determined under the controlled condition with the concentration of $1 \times 10^{7}$ conidia $\mathrm{mL}^{-1}$ and showed that three strains of B. bassiana (BAU019, BAU004, and BAU018) showed high effect on aphids, with a mortality of over 75\% [34,41-44]. According to filtrate treatment, our results are similar to results which revealed that degradation of the insect body was observed at higher infiltrate treated aphids, and the reduction of aphid population was higher in higher dose filtrate treatment [27]. The maximum efficacy was due to the production of metabolites in the culture filtrate that helped to degrade the cuticle and deform the hemocoel. As compared with the filtrate, conidia need more time to germinate and release the required enzymes for the degradation of the insect body. It was demonstrated that the use of filtrate 
application for the control of insects was the best method, and also effective for insects which had a short life cycle because these insects have more chances to shed the conidia from their body by molting, since germination of conidia needs a specific time [45,46]. According to their findings, our results were similar. Filtrate had more ability to control the insect population, because they contained toxic enzymes for the degradation of the insect body. Through filtrate optimization, the production of enzymes could be enhanced easily with fungal genetic manipulation. Filtrate production, storage, and transportation are more suitable than conidia, and it meets the commercialization requirements. In this study, the effect of different fungal strains was found to be time dependent in cases of conidia, filtrate suspension, and combinations. The maximal effect was recorded after eight days, while the minimal effect was recorded after two days. These results are similar to research that showed an increase in the effect with the increase in time and concentration [39].

Regarding the pathogenicity of different fungal combinations, our results showed that the highest synergistic effects were a combination of fungal strains (B76 + L5, and L2 + B76). However, there was no synergistic effect for the combination of fungal strains L2 + B252 and L2 + B76 + B252 + L5 . These fungal strains may show synergies if applied in a sequential combination, as demonstrated in the case of nematodes and pathogenic fungi [47]. Therefore, the use of the entomopathogenic fungi is considered safe and environmentally friendly compared to chemical pesticides [48], so they are recommended against harmful pests, such as aphids.

\section{Materials and Methods}

\subsection{Insect Culture}

Bean aphids were collected from the Institute of Plant Protection, Beijing, China. Then, they were reared on Chinese cabbage plants (Brassica rapa) placed in cages in the growth chamber at $50-60 \%$ relative humidity and $25 \pm 2{ }^{\circ} \mathrm{C}$, with a $16: 8 \mathrm{~h}$ light:dark photoperiod. The first instar aphid was used for all bioassays in this study.

\subsection{Fungal Isolates}

All fungal isolates (Table 4) were collected from fields in China and cultured on potato dextrose agar (PDA) medium (20.0 g agar, $200.0 \mathrm{~g}$ potatoes, $20.0 \mathrm{~g}$ dextrose, and $1 \mathrm{~L}$ distilled water) on Petri-dishes for 20 days in the dark at $25 \pm 2{ }^{\circ} \mathrm{C}$.

Table 4. Name of fungal strains, hosts and geographical of the entomopathogenic fungi.

\begin{tabular}{ccc}
\hline Name & Symbols & Geographical Origin \\
\hline Verticilliun lecanii 2 & L2 & Institute of Plant Protection, Beijing, China \\
Verticilliun lecanii 5 & L5 & Institute of Plant Protection, Beijing, China \\
Beauveria bassiana 76 & B76 & Institute of Plant Protection, Beijing, China \\
Beauveria bassiana 252 & B252 & Institute of Plant Protection, Beijing, China \\
\hline
\end{tabular}

\subsection{Conidial Suspension}

The conidia were collected from PDA dishes in $0.02 \%$ Tween solution after 20 days culture and were filtered using sterile cheesecloth. The spore concentrations of all fungal strains were counted under the microscope using a hemocytometer. The conidia viability was checked before using for the design of the bioassays experiment [49].

\subsection{Fungal Filtrate}

The primary culture of the four strains (B76, B252, L2, and L5) was prepared by mixing $100 \mathrm{~mL}$ of Adamek liquid medium (ALM) with $5 \mathrm{~mL}$ of conidial suspension and shaken for 3 days at $150 \mathrm{rpm}$. The secondary culture (1.0\%) was prepared by mixing $250 \mathrm{~mL}$ of ALM with $2.5 \mathrm{~mL}$ of the primary culture medium and shaken for 6 days at $150 \mathrm{rpm}, 25^{\circ} \mathrm{C}$. The mycelium was removed by centrifugation 
for $15 \mathrm{~min}$ at $12,000 \mathrm{rpm}, 4^{\circ} \mathrm{C}$ and then the supernatant was filtered through the $0.45 \mu \mathrm{m}$ pore-size filter (Millipore Corp) to get the filtrate.

\subsection{Pathogenicity Bioassays}

The effect of the entomopathogenic fungal strains (B76, B252, L2, and L5) against bean aphids was measured by conducting their conidial and filtrate bioassays, and evaluating the binary combinations of different fungal strains. All bioassays were measured using the leaf-dip method [50] with slight modifications. All treatments were performed on $90 \mathrm{~mm}$ Petri dishes containing a thin layer of $1.0 \%$ agar, and a $60 \mathrm{~mm}$ detached leaf disk of Chinese cabbage was placed on the Petri dish. The control leaves were dipped only in $0.02 \%$ Tween. Fifty newly molted bean aphids up to $12 \mathrm{~h}$ old (first instar) were released on the treated and control leaf on a Petri dish, and then they were stored at $50-60 \%$ relative humidity and $25 \pm 2{ }^{\circ} \mathrm{C}$ with a $16: 8 \mathrm{~h}$ light:dark photoperiod. All the treatments were replicated 3 times (each treatment has 5 Petri dishes for each time). For the bioassay treatment of binary combination, the uppermost concentration $1 \times 10^{8}$ conidia $\mathrm{mL}^{-1}$ of each fungal strain was mixed with the $1 \mathrm{~mL}$ conidia of each other fungal strain for all combinations, and then a $2 \mathrm{~mL}$ mixed combination sample for each treatment was collected. The combinations, L2 + B76, B76 + L5, L2 + B525, and L2 + B76 + B252 + L5 were designed. For all treatments, the effect was recorded on 2, 4, 6 and 8 days. All dead bean aphids from each experiment were maintained at $25 \pm 2{ }^{\circ} \mathrm{C}$ and $90 \%$ relative humidity in dark to confirm mortality by the pathogens. The effect of all fungal strains was determined using Abbott's formula: Effect $(\%)=(X-Y) / X) \times 100(X$ : the percent living in the control; Y: the percent living in the treatment) [51].

\subsection{Data Analysis}

The data was analyzed using Statistix 8.1 (Analytical Software, Tallahassee, FL, USA). Comparisons of the treatment means were performed, using variances (ANOVA) to determine the significance of individual differences of the least significant difference (LSD) test at $\alpha=0.05$ level.

\section{Conclusions}

In brief, this study shows the effect of four different fungal strains of V. lecanii (L2 and L5) and $B$. bassiana (B76 and B252) against $M$. japonica. Through a series of bioassays, the results demonstrated that different fungal strains of V. lecanii (L2 and L5) and B. bassiana (B76 and B252) have different virulence potential. The different application materials and their dosages also affect pathogenicity on bean aphid. Filtrate application is the most suitable material for the control of M. japonica. In the combination of bioassays, the binary combination of strains of B76 and L2 exhibited high mortality of bean aphid $(90.5 \%)$. Thus, the results of this study suggest that these fungal strains may be used as novel biological control agents against bean aphids.

Author Contributions: Conceptualization, D.Q. and D.N.T.; Investigation, D.N.T.; Data Curation, D.N.T. and T.K.L.H.; Writing Original Draft Preparation, D.N.T.; Writing—Review \& Editing, D.Q. and D.N.T.; Supervision, D.Q.; Funding Acquisition, D.Q. All authors have read and agreed to the published version of the manuscript.

Acknowledgments: We are especially thankful to the China Scholarship Council (CSC) for providing a Ph.D. scholarship.

Conflicts of Interest: The authors declare no conflict of interest.

\section{References}

1. Zhang, S.Z.; Cao, Z.; Wang, Q.L.; Zhang, F.; Liu, T.X. Exposing eggs to high temperatures affects the development, survival and reproduction of Harmonia axyridis. J. Therm. Biol. 2014, 39, 40-44. [CrossRef]

2. Jiadong, Y.; Yanhui, L.; Li, X.; Mo, W.; Cong, Z.; Jing, W.; Xin, T.; Zou, Z.; Xia, B. Predation of Cheyletus malaccensis (Acari: Cheyletidae) on Megoura japonica (Hemiptera: Aphididae) under five different temperatures. Int. J. Acarol. 2019, 45, 176-180. [CrossRef] 
3. Diaz, B.M.; Oggerin, M.; Lastra, C.C.L.; Rubio, V.; Fereres, A. Characterization and virulence of Lecanicillium lecanii against different aphid species. BioControl 2009, 54, 825-835. [CrossRef]

4. Blair, A.; Ritz, B.; Wesseling, C.; Freeman, L.B. Pesticides and Human Health; BMJ Publishing Group Ltd.: London, UK, 2015.

5. Majeed, M.Z.; Fiaz, M.; Ma, C.S.; Afzal, M. Entomopathogenicity of Three Muscardine Fungi, Beauveria bassiana, Isaria fumosorosea and Metarhizium anisopliae, against the Asian Citrus Psyllid, Diaphorina citri Kuwayama (Hemiptera: Psyllidae). Egypt. J. Biol. Pest Control 2017, 27, 211-215.

6. Motta-Delgado, P.A.; Murcia-Ordoñez, B. Hongos entomopatógenos como alternativa para el control biológico de plagas. Ambiente Água Interdiscip. J. Appl. Sci. 2011, 6, 77-90.

7. Sahayaraj, K.; Namachivayam, S. Field evaluation of three entomopathogenic fungi on groundnut pests. Tropicultura 2011, 29, 143-147.

8. Scholte, E.-J.; Knols, B.G.; Samson, R.A.; Takken, W. Entomopathogenic fungi for mosquito control: A review. J. Insect Sci. 2004, 4, 19. [CrossRef]

9. Tanzini, M.R.; Batista, S.; Setten, A.; Toschi, N. Compatibilidad de agentes tensoactivos con Beauveria bassiana and Metarhizium anisopliae. Manejo Integrado Plagas Costa Rica 2001, 59, 15-18.

10. Cabanillas, H.E.; Jones, W.A. Pathogenicity of Isaria sp. (Hypocreales: Clavicipitaceae) against the sweet potato whitefly B biotype, Bemisia tabaci (Hemiptera: Aleyrodidae). Crop Prot. 2009, 28, 333-337. [CrossRef]

11. Landa, Z.; Osborne, L.; Lopez, F.; Eyal, J. A Bioassay for Determining Pathogenicity of Entomogenous Fungi on Whiteflies1. Biol. Control 1994, 4, 341-350. [CrossRef]

12. Mus,tu, M.; Demirci, F.; Kaydan, M.B.; Ülgentürk, S. Laboratory assay of the effectiveness of the entomopathogenic fungus Isaria farinosa (Holmsk.) Fries (Sordariomycetes: Hypocreales) against the vine mealybug Planococcus ficus (Signoret) (Hemiptera: Pseudococcidae), even under the use of fungicides. Int. J. Pest Manag. 2015, 61, 264-271. [CrossRef]

13. Ekesi, S.; Dimbi, S.; Maniania, N. The Role of Entomopathogenic fungi in the Integrated Management of Fruit Flies (Diptera: Tephritidae) with Emphasis on Species Occurring in Africa; Research SignPost: Kerala, India, 2007; Volume 37, pp. 239-274.

14. Nasir, M.; Hussain, M.; Iqbal, B.; Shehzad, M.A.; Ali, S.; Abbas, W.; Javed, M.M.; Hussain, S. A Review on Whitefly Control by the Use of Entomopathogenic Fungi. In Proceedings of the 8th National Conference of Plant Pathology, University of Agriculture, Faisalabad, Pakistan, 28-29 November 2011; pp. 28-40.

15. Copping, L.G. The Manual of Biocontrol Agents; British Crop Protection Council: Alton, UK, 2004.

16. Zimmermann, G. Review on safety of the entomopathogenic fungi Beauveria bassiana and Beauveria brongniartii. Biocontrol Sci. Technol. 2007, 17, 553-596. [CrossRef]

17. Annamalai, M.; Kaushik, H.; Selvaraj, K. Bioefficacy of Beauveria bassiana (Balsamo) Vuillemin and Lecanicillium lecanii Zimmerman against Thrips tabaci Lindeman. Proc. Natl. Acad. Sci. USA India Sect. B Biol. Sci. 2016, 86, 505-511. [CrossRef]

18. Dogan, Y.O.; Hazir, S.; Yildiz, A.; Butt, T.M.; Cakmak, I. Evaluation of entomopathogenic fungi for the control of Tetranychus urticae (Acari: Tetranychidae) and the effect of Metarhizium brunneum on the predatory mites (Acari: Phytoseiidae). Biol. Control 2017, 111, 6-12. [CrossRef]

19. Freed, S.; Jin, F.-L.; Ren, S.-X. Phylogenetics of entomopathogenic fungi isolated from the soils of different ecosystems. Pak. J. Zool. 2011, 43, 417-425.

20. Meyling, N.V.; Pell, J.K.; Eilenberg, J. Dispersal of Beauveria bassiana by the activity of nettle insects. J. Invertebr. Pathol. 2006, 93, 121-126. [CrossRef]

21. Saruhan, I. Efficacy of some entomopathogenic fungi against Aphis fabae Scopoli (Hemiptera: Aphididae). Egypt. J. Biol. Pest Control 2018, 28, 89. [CrossRef]

22. Isaka, M.; Kittakoop, P.; Kirtikara, K.; Hywel-Jones, N.L.; Thebtaranonth, Y. Bioactive substances from insect pathogenic fungi. Acc. Chem. Res. 2005, 38, 813-823. [CrossRef]

23. Lozano-Tovar, M.; Ortiz Urquiza, A.; Garrido-Jurado, I.; Trapero-Casas, A.; Quesada-Moraga, E. Assessment of entomopathogenic fungi and their extracts against a soil-dwelling pest and soil-borne pathogens of olive. Biol. Control 2013, 67, 409-420. [CrossRef]

24. Shin, T.Y.; Bae, S.M.; Kim, D.J.; Yun, H.G.; Woo, S.D. Evaluation of virulence, tolerance to environmental factors and antimicrobial activities of entomopathogenic fungi against two-spotted spider mite, Tetranychus urticae. Mycoscience 2017, 58, 204-212. [CrossRef]

25. Samson, R.; Evans, H.; Latgé, J. Atlas of Entomopathogenic Fungi; Springer: New York, NY, USA, 1988. 
26. Khan, S.; Guo, L.; Shi, H.; Mijit, M.; Qiu, D. Bioassay and enzymatic comparison of six entomopathogenic fungal isolates for virulence or toxicity against green peach aphids Myzus persicae. Afr. J. Biotechnol. 2012, 11, 14193-14203. [CrossRef]

27. Kim, J.S.; Roh, J.Y.; Choi, J.Y.; Wang, Y.; Shim, H.J.; Je, Y.H. Correlation of the aphicidal activity of Beauveria bassiana SFB-205 supernatant with enzymes. Fungal Biol. 2010, 114, 120-128. [CrossRef] [PubMed]

28. Quesada-Moraga, E.; Carrasco-Díaz, J.A.; Santiago-Álvarez, C. Insecticidal and antifeedant activities of proteins secreted by entomopathogenic fungi against Spodoptera littoralis (Lep., Noctuidae). J. Appl. Entomol. 2006, 130, 442-452. [CrossRef]

29. Wang, C.; St Leger, R.J. The MAD1 adhesin of Metarhizium anisopliae links adhesion with blastopore production and virulence to insects, and the MAD2 adhesin enables attachment to plants. Eukaryotic Cells 2007, 6, 808-816. [CrossRef] [PubMed]

30. Fazeli-Dinan, M.; Talaei-Hassanloui, R.; Goettel, M. Virulence of the entomopathogenic fungus Lecanicillium longisporum against the greenhouse whitefly, Trialeurodes vaporariorum and its parasitoid Encarsia formosa. Int. J. Pest Manag. 2016, 62, 251-260. [CrossRef]

31. Amnuaykanjanasin, A.; Jirakkakul, J.; Panyasiri, C.; Panyarakkit, P.; Nounurai, P.; Chantasingh, D.; Eurwilaichitr, L.; Cheevadhanarak, S.; Tanticharoen, M. Infection and colonization of tissues of the aphid Myzus persicae and cassava mealybug Phenacoccus manihoti by the fungus Beauveria bassiana. BioControl 2013, 58, 379-391. [CrossRef]

32. Yun, H.G.; Kim, D.J.; Gwak, W.S.; Shin, T.Y.; Woo, S.D. Entomopathogenic Fungi as Dual Control Agents against Both the Pest Myzus persicae and Phytopathogen Botrytis cinerea. Mycobiology 2017, 45, 192-198. [CrossRef]

33. Hesketh, H.; Alderson, P.G.; Pye, B.J.; Pell, J.K. The development and multiple uses of a standardised bioassay method to select hypocrealean fungi for biological control of aphids. Biol. Control 2008, 46, 242-255. [CrossRef]

34. Halimona, J.; Jankevica, L. The influence of Entomophthorales isolates on aphids Aphis fabae and Metopeurum fuscoviride. Latvijas Entomologs 2011, 50, 55-60.

35. Liu, H.; Skinner, M.; Parker, B.L.; Brownbridge, M. Pathogenicity of Beauveria bassiana, Metarhizium anisopliae (Deuteromycotina: Hyphomycetes), and other entomopathogenic fungi against Lygus lineolaris (Hemiptera: Miridae). J. Econ. Entomol. 2002, 95, 675-681. [CrossRef]

36. Wright, M.S.; Raina, A.K.; Lax, A.R. A strain of the fungus Metarhizium anisopliae for controlling subterranean termites. J. Econ. Entomol. 2005, 98, 1451-1458. [CrossRef] [PubMed]

37. Ansari, M.; Vestergaard, S.; Tirry, L.; Moens, M. Selection of a highly virulent fungal isolate, Metarhizium anisopliae CLO 53, for controlling Hoplia philanthus. J. Invertebr. Pathol. 2004, 85, 89-96. [CrossRef] [PubMed]

38. Akmal, M.; Freed, S.; Malik, M.N.; Gul, H.T. Efficacy of Beauveria bassiana (Deuteromycotina: Hypomycetes) against different aphid species under laboratory conditions. Pak. J. Zool. 2013, 45, 71-78.

39. Loureiro, E.D.S.; de Oliveira, N.C.; Wilcken, C.F.; Batista Filho, A. Patogenicidade de Verticillium lecanii ao pulgão-do-pinus. Revista Árvore 2004, 28, 765-770. [CrossRef]

40. Ashouri, A.; Arzanian, N.; Askary, H.; Rasoulian, G.R. Pathogenicity of the fungus, Verticillium lecanii, to the green peach aphid, Myzus persicae (Hom.: Aphididae). Commun. Agric. Appl. Boil. Sci. 2004, 69, 205-209.

41. Abdelaziz, O.; Senoussi, M.M.; Oufroukh, A.; Birgücü, A.K.; Karaca, İ.; Kouadri, F.; Naima, B.; Bensegueni, A. Pathogenicity of three entomopathogenic fungi, to the aphid species, Metopolophium dirhodum (Walker) (Hemiptera: Aphididae), and their Alkaline protease activities. Egypt. J. Biol. Pest Control 2018, 28, 1-5. [CrossRef]

42. Al-alawi, M.S.; Obeidat, M. Selection of Beauveria bassiana (Balsamo) Vuillemin isolates for management of Myzus persicae (Sultzar) (Hom.: Aphidae) based on virulence and growth-related characteristics. Am. J. Agric. Biol. Sci. 2014, 9, 94. [CrossRef]

43. Al-Keridis, L.A. Entomopathogenic Fungi as A biological Control Agents on green peach aphid, Myzus persicae in Potatoes Crop. Int. J. ChemTech Res. 2017, 10, 378-385.

44. Jandricic, S.E.; Filotas, M.; Sanderson, J.P.; Wraight, S.P. Pathogenicity of conidia-based preparations of entomopathogenic fungi against the greenhouse pest aphids Myzus persicae, Aphis gossypii, and Aulacorthum solani (Hemiptera: Aphididae). J. Invertebr. Pathol. 2014, 118, 34-46. [CrossRef]

45. Altre, J.; Vandenberg, J. Factors influencing the infectivity of isolates of Paecilomyces fumosoroseus against diamondback moth, Plutella xylostella. J. Invertebr. Pathol. 2001, 78, 31-36. [CrossRef] 
46. Bateman, R.; Alves, R. Delivery systems for mycoinsecticides using oil-based formulations. Asp. Appl. Biol. 2000, 57, 163-170.

47. Anbesse, S.; Gebru, W.; Adge, B. Laboratory screening for virulent entomopathogenic nematodes (Heterorhabditis bacteriophora and Steinernema yirgalemense) and fungi (Metarhizium anisopliae and Beauveria bassiana) and assessment of possible synergistic effects of combined use against grub. Nematology 2008, 10, 701-709. [CrossRef]

48. Goettel, M.S.; Jaronski, S.T. Safety, and registration of microbial agents for control of grasshoppers and locusts. Mem. Entomol. Soc. Can. 1997, 129, 83-99. [CrossRef]

49. Hywel-Jones, N.L.; Gillespie, A.T. Effect of temperature on spore germination in Metarhizium anisopliae and Beauveria bassiana. Mycol. Res. 1990, 94, 389-392. [CrossRef]

50. Xu, J.H.; Feng, M.G. Pandora delphic is (Entomophthorales: Entomophthoraceae) infection affects the fecundity and population dynamics of Myzus persicae (Homoptera: Aphididae) at varying regimes of temperature and relative humidity in the laboratory. Biol. Control 2002, 25, 85-91. [CrossRef]

51. Abbott, W.S. A method of Computing the Effectiveness of an Insecticide. J. Econ. Entomol. 1925, 18, $265-267$. [CrossRef]

(C) 2020 by the authors. Licensee MDPI, Basel, Switzerland. This article is an open access article distributed under the terms and conditions of the Creative Commons Attribution (CC BY) license (http://creativecommons.org/licenses/by/4.0/). 